\title{
Periodontal treatment influences risk markers for atherosclerosis in patients with severe periodontitis
}

\author{
Kåre Buhlin ${ }^{\mathrm{a}, *}$, Margareta Hultin ${ }^{\mathrm{a}, \mathrm{b}}$, Ola Norderyd ${ }^{\mathrm{c}, \mathrm{h}}$, Lena Persson ${ }^{\mathrm{b}}$, A. Graham Pockley $^{\mathrm{d}}$, \\ Pirkko J. Pussinen ${ }^{\mathrm{e}, \mathrm{f}}$, Per Rabe ${ }^{\mathrm{g}}$, Björn Klinge ${ }^{\mathrm{a}}$, Anders Gustafsson ${ }^{\mathrm{a}}$ \\ a Dept. of Periodontology, Institute of Odontology, Karolinska Institutet, Huddinge, Sweden \\ ${ }^{\mathrm{b}}$ Dept. of Periodontology, Division of Specialist Dental Care, Mälar Hospital, Eskilstuna, Sweden

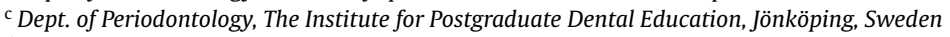 \\ d School of Medicine and Biomedical Sciences, University of Sheffield, Sheffield, UK \\ e Institute of Dentistry, University of Helsinki, Helsinki, Finland \\ ${ }^{\mathrm{f}}$ Dept. of Oral and Maxillofacial Diseases, Helsinki University Central Hospital, Helsinki, Finland \\ ${ }^{g}$ Dept. of Periodontology, Division of Specialist Dental Care in Halland, County Hospital, Halmstad, Sweden

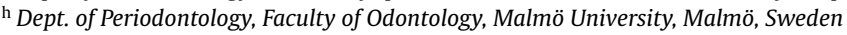

\section{A R T I C L E I N F O}

\section{Article history:}

Received 19 December 2008

Received in revised form 23 March 2009

Accepted 24 March 2009

Available online $\mathrm{xxx}$

\section{Keywords:}

Atherosclerosis

Inflammation

Longitudinal study

Periodontitis

Risk factors

Treatment

\begin{abstract}
A B S T R A C T
This study investigated the effect of mechanical infection control for periodontitis and periodontal surgery on the prevalence of well-established risk factors for atherosclerosis, and plasma levels of cytokines, antibodies against heat shock proteins and markers of systemic inflammation.

Sixty-eight patients between 39 and 73 years of age with severe periodontitis who had been referred to four specialist periodontology clinics in Sweden were investigated. A fasting venous blood sample was taken at baseline and additional samples were collected after 3 and 12 months. A total of 54 patients underwent periodontal treatment.

The periodontal treatment was successful, as pathogenic gingival pockets decreased significantly. Plasma glucose, lipids and markers of systemic inflammation were not significantly altered after 3 months. One year after the initial treatment, HDL-C concentrations were significantly increased $(\Delta 0.08 \mathrm{mmol} / \mathrm{L})$ whereas LDL-C concentrations decreased $(\Delta 0.23 \mathrm{mmol} / \mathrm{L})$. Haptoglobin concentrations were also lower. Interleukin-18 and interferon- $\gamma$ levels were also lower after 12 months $(60 \mathrm{ng} / \mathrm{L}(-23 \%)$ and $11 \mathrm{ng} / \mathrm{L}(-97 \%)$ respectively). Treatment had no effect on plasma levels of IgA, IgG1, IgG2 antibodies against heat shock proteins.

In conclusion, this study indicates that standard treatment for periodontal disease induces systemic changes in several biochemical markers that reflect the risk for atherosclerosis.
\end{abstract}

(C) 2009 Elsevier Ireland Ltd. All rights reserved.

\section{Introduction}

Periodontitis is a chronic tissue-destructive inflammatory state which is predominantly induced by Gram negative bacteria colonizing the gingival crevice. The disease degrades the attachment apparatus of the teeth, leading to tooth loosening and eventually, in its most severe form, to tooth loss. Periodontitis is a common disease; the U.S. National Health and Nutrition Examination Survey 1999-2000 (NHANES) reported a prevalence of $4.2 \%$ among adult Americans [1]. Conventional treatment of periodontitis comprises mechanical removal of supra- and subgingival bacteria which

* Corresponding author at: Dept. of Periodontology, Karolinska Institutet, Alfred Nobels Allé 8, Box 4064, 14104 Huddinge, Sweden. Tel.: +46 852488 276; fax: +4687118343.

E-mail address: Kare.Buhlin@ki.se (K. Buhlin). decreases inflammation and promotes clinical signs of healing and repair.

A meta-analysis of longitudinal and cross-sectional studies recently demonstrated that patients with periodontitis are at a significantly elevated relative risk of developing cardiovascular disease (CVD) [2]. One possible explanation for this could be the spread of bacteria and bacterial products into the circulation, and in this respect DNA from oral bacteria has been found in atherosclerotic plaques [3]. Periodontal pathogens and their products have been reported and purported to trigger the atherosclerotic process in animal and human studies [4-6]. In addition to the spread of bacteria, the release of host-derived inflammatory mediators such as C-reactive protein (CRP) and cytokines from the chronically inflamed periodontal tissues into the circulation might provide a link between periodontal disease and CVD, as it is known that chronic infection and inflammation predispose individuals to the development of CVD (for review see van Leuven et al. [7]).

0021-9150/\$ - see front matter @ 2009 Elsevier Ireland Ltd. All rights reserved. doi:10.1016/j.atherosclerosis.2009.03.035 
We have previously reported that levels of CRP and lipoproteins are significantly different in those with periodontitis compared with a healthy control group [8]. It is not clear whether these differences trigger or are a consequence of the local inflammation in the periodontium. Thus, the aim of the present study was to investigate the effect of a clinically successful mechanical infection control protocol on well-established risk factors for CVD such as hyperglycemia and dyslipidemia. Furthermore, we investigated the effect of periodontal treatment on the levels of plasma cytokines, antibodies against heat shock proteins and markers of systemic inflammation.

\section{Methods}

\subsection{Participants}

Sixty-eight patients (all Caucasians; 36 women) with severe periodontitis (having a minimum of seven sites exhibiting at least $6 \mathrm{~mm}$ loss of clinical attachment) participated in the clinical examination and blood sampling. Twenty-nine (43\%) of the participants were current smokers. The mean age was $53.8 \pm 7.9$ years. To be included in the study, patients had to have a chronic generalized severe periodontitis [13] and be between 35 and 70 years of age. They also had to be overtly healthy and free of CVD, not to be taking any medications for CVD and not to be suffering from any known systemic diseases. Their mean body mass index (BMI) was 25.9 (SD 3.3). Patients meeting the inclusion and exclusion criteria were consecutively selected.

All participants gave their informed consent. This study was approved by the Regional Ethics Committee of the Karolinska Institutet, and it was conducted in accordance with the Helsinki Declaration.

\subsection{Clinical examination for periodontal disease}

Patients underwent a comprehensive periodontal examination including radiographs. A total of four dentists, all with extensive experience in the field of periodontology, undertook the clinical examinations. The examiners were given detailed instructions beforehand. Teeth and gingivae were evaluated, and pocket depths were measured using a calibrated periodontal probe. Probing depth is the distance between the gingival margin and the bottom of the gingival pocket measured from six angles of each tooth. Gingival pockets of $4 \mathrm{~mm}$ or deeper were considered to be pathological. Gingival inflammation was noted as bleeding on probing and data are expressed as the proportion of bleeding sites among the total number of sites in the dentition. A first fasting blood sample was taken after the examination, but before treatment began.

\subsection{Clinical treatment of periodontal disease}

Patients underwent a thorough periodontal treatment, including extractions of hopeless teeth due to periodontitis, caries lesions or endodontic reasons. Oral hygiene instructions were given and scaling and root planing was performed. This is the standard care for reducing periodontal inflammation. The treatment continued until the patient achieved a good status of oral hygiene by him/herself and was free from clinically detectable calculus [13]. Patients were re-examined according to the baseline criteria after 3 months and a second blood sample was taken. For those who still had pockets deeper than $6 \mathrm{~mm}$, a standardized periodontal muco-periostal flap surgical procedure was performed [9]. The patients were reexamined and a final fasting blood sample was taken after 12 months (see Fig. 1).

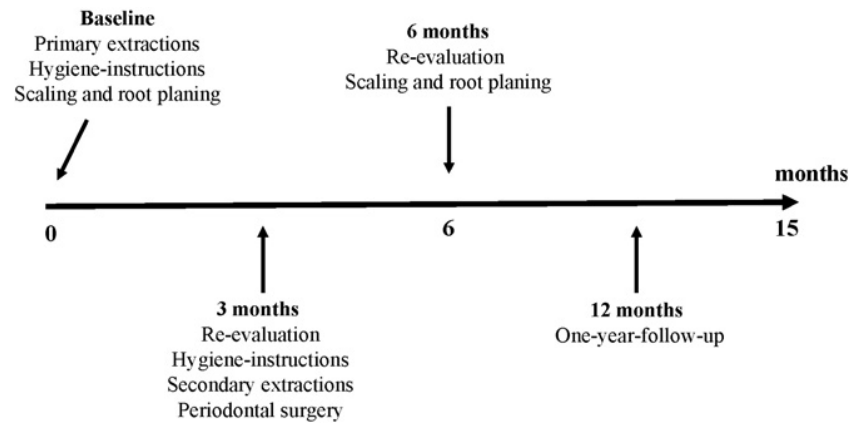

Fig. 1. Timeline regarding the treatment during the 12-month study period.

\section{Laboratory analyses}

Blood was collected into Vacutainer ${ }^{\mathrm{TM}}$ tubes containing EDTA and hematological parameters were determined using a Coulter STKS analyzer (Coulter Electronics Inc., Hialeah, FL, USA). Plasma was obtained after centrifugation at $1500 \times \mathrm{g}$ for $10 \mathrm{~min}$ and stored at $-70^{\circ} \mathrm{C}$. Total cholesterol, low density lipoproteins cholesterol (LDL-C) and high density lipoprotein cholesterol (HDL-C) concentrations were determined using standard clinical chemistry procedures with a Hitachi 917 analyzer (Roche AG Diagnostics, Mannheim, Germany). The lipid profile was calculated as the ratio between total cholesterol and HDL-C. CRP concentrations were determined using a high-sensitivity commercial assay kit (DADE Behring, Deerfield, IL, USA), and haptoglobin and fibrinogen concentrations were measured using a BNA nephelometer (Behringwerke AG Diagnostica, Marburg, Germany).

Interleukin (IL)-1 $\beta$, IL-4, IL-5, IL-6, IL-8, IL-10, interferon- $\gamma$ (IFN- $\gamma$ ) and tumor necrosis factor- $\alpha$ (TNF- $\alpha$ ) concentrations were determined by Multiplex bead analysis using a Luminex 100 (Luminex Corp., Austin, TX, USA) and commercial immunoassays (Lincoplex, high-sensitivity human cytokine panel, Linco Research Inc., St. Charles, MO, USA). IL-18 concentrations were determined using a commercial immunoassay kit according to the manufacturers' recommended protocols (R\&D Systems Europe Ltd., Abingdon, UK). Glucose concentrations were determined using a BeckmanCoulter LX analyzer (Beckman-Coulter Inc., Fullerton, CA, USA). All blood analyses were performed blindly.

Levels of plasma antibodies against human Hsp60 (kindly provided by Professor Willem van Eden and Dr. Ruurd van der Zee, Utrecht University, Utrecht, The Netherlands), mycobacterial Hsp65 (kindly provided by Professor Anthony Coates, St. George's Hospital Medical School, London, UK), and human Hsp70 (kindly provided by Professor Gabriele Multhoff, Klinikum rechts der Isar (Technische Universität München), Munich and Helmholtz Zentrum München, German Research Center for Environmental Health, Neuherberg, Germany) were determined as described previously [8,10], except that the levels of specific antibody isotypes/sub-types (IgA, IgG1, IgG2) were determined. Data are presented as the absorbance values that were generated by $1 / 100$ dilutions of the samples. All samples were analyzed at the same time and under identical conditions.

\subsection{Statistical methods}

The data were analyzed using a mixed model in Procedure Mixed in $S A S^{\circledR}$ in order to establish whether there were any treatment effects over time (three time points) on lipid and inflammatory variables. Post hoc comparisons between visits were undertaken if the $F$-test was significant. The $p$-values were adjusted according to Tukey's procedure. Since the distribution of some variables was 
Table 1

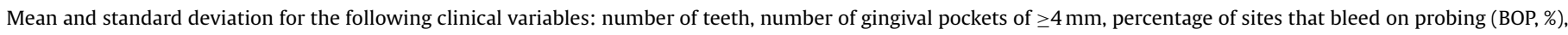
proportion of sites with dental plaque (\%).

\begin{tabular}{|c|c|c|c|c|c|c|c|c|c|}
\hline \multirow[t]{2}{*}{ Variable } & \multicolumn{3}{|l|}{ Baseline } & \multicolumn{3}{|c|}{ 3-month follow-up } & \multicolumn{3}{|c|}{ 12-month follow-up } \\
\hline & All $(n=68)$ & $\begin{array}{l}\text { Non-smokers } \\
(n=39)\end{array}$ & $\begin{array}{l}\text { Smokers } \\
(n=29)\end{array}$ & All $(n=60)$ & $\begin{array}{l}\text { Non-smokers } \\
(n=35)\end{array}$ & $\begin{array}{l}\text { Smokers } \\
(n=25)\end{array}$ & All $(n=54)$ & $\begin{array}{l}\text { Non-smokers } \\
(n=32)\end{array}$ & $\begin{array}{l}\text { Smokers } \\
(n=22)\end{array}$ \\
\hline $\begin{array}{l}\text { Number of } \\
\text { teeth }\end{array}$ & $24.2(4.6)$ & $24.4(4.1)$ & $24.0(5.2)$ & $22.6(5.3)$ & $22.5(4.8)$ & $22.9(6.0)$ & $22.2(5.4)$ & $22.1(4.9)$ & $22.4(5.2)$ \\
\hline $\begin{array}{c}\text { Number of } \\
\text { pockets }\end{array}$ & $47.5(16.6)$ & $44.7(17.3)$ & $51.2(15.1)$ & $25.2(14.9)$ & $21.7(11.5)$ & $\begin{array}{l}30.2(17.2) \\
p<0.03\end{array}$ & $19.6(14.2)$ & $16.6(10.8)$ & $24.0(17.0)$ \\
\hline BOP (\%) & $44.6(15.6)$ & $43.3(14.8)$ & $46.3(16.9)$ & $21.8(13.8)$ & $18.7(10.6)$ & $\begin{array}{l}26.2(16.8) \\
p<0.04\end{array}$ & $15.1(11.8)$ & $11.9(7.8)$ & $\begin{array}{l}19.7(15.0), \\
p<0.02\end{array}$ \\
\hline $\begin{array}{l}\text { Oral plaque } \\
\text { (\%) }\end{array}$ & $51.0(21.9)$ & $52.1(23.6)$ & $49.6(19.8)$ & $20.0(19.7)$ & $18.5(17.7)$ & $22.1(22.3)$ & $16.3(15.6)$ & $13.2(11.8)$ & $20.9(19.3)$ \\
\hline
\end{tabular}

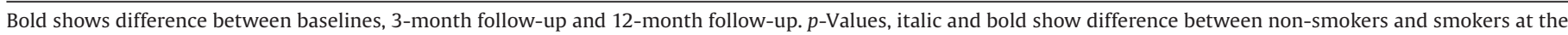
indicated time-point.

positively skewed, log transformation and square root transformation were performed before the analyses. Significant differences between smokers and non-smokers were calculated using the Mann-Whiney $U$-test or Student's $t$-test. Correlative statistics were undertaken using the Spearman Rank Order test. Statistical calculations were made with Statistica 8.0, StatSoft ${ }^{\circledR}$ Inc., Tulsa, OK, USA, and SAS ${ }^{\circledR}$ System 9.1, SAS Institute Inc., Cary, NC, USA.

\section{Results}

Of the 68 patients that were initially identified to be included in the study, 54 completed the 1-year follow-up period. The other 14 failed to complete their treatment plan due to various reasons, such as lack of money, interest or the fact that they had moved and declined to participate. Gender distribution, smoking, mean age, BMI, CRP, glucose and cholesterol concentrations at baseline did not differ between all participants and those continuing the study. To our knowledge, none of the individuals in the smoking group stopped smoking during the study period.

The clinical outcome of the treatment program is shown in Table 1 . The treatment successfully reduced the intensity of local infection and inflammation. Clinical markers of the disease, pathogenic gingival pockets ( $\geq 4 \mathrm{~mm}$ ), bleeding on probing (BOP, gingivitis) and visual bacterial plaque were decreased significantly. There were no differences between smokers and non-smokers at baseline. However, significant differences in the number of pockets and BOP after 3 months and BOP after 12 months between smokers and non-smokers were apparent, thereby indicating that smokers were somewhat less responsive to treatment. Possible correlations between clinical status and plasma variables were tested at baseline. None of the investigated plasma variables were correlated with the clinical status.

Plasma glucose, lipids and the markers of systemic inflammation were not significantly different at the 3-month follow-up. One year after the initial treatment, glucose and HDL-C concentrations were significantly higher than baseline $(\Delta 0.08 \mathrm{mmol} / \mathrm{L})$, whereas LDL-C concentrations were lower $(\Delta 0.23 \mathrm{mmol} / \mathrm{L})$. The lipid profile and haptoglobin concentration were also lower than baseline at this time (Tables 2 and 3). IL-18 levels were decreased after 3 and 12 months, with the median decrease at 12 months being $60 \mathrm{ng} / \mathrm{L}(-23 \%)$. The decreases in IL-18 and IFN- $\gamma$ levels did not correlate with the observed clinical improvements in periodontal health. Treatment had no effect on the levels of any of the other cytokines measured, and there were no correlations between the dental parameters and the changes in lipid levels.

The concentrations of IgA, IgG1, IgG2 antibodies against human Hsp60, mycobacterial Hsp65 and human Hsp70 were not influenced by periodontal treatment (data not shown).

\section{Discussion}

This intervention study indicates that periodontal treatment influences blood lipid levels in a manner which is consistent with a decreased risk for CVD. HDL-C concentrations increased and LDL-C concentrations decreased significantly. The changes were modest; LDL-C concentrations decreased by $6 \%$. HDL-C concentrations slowly increased during the 12-month study period, which corresponds well with the periodontal infection treatment. Both chronic and acute infections decreased circulating HDL-C concentrations by various mechanisms, including an increase in apolipoprotein AI catabolism and changes in HDL-C subclass distribution [11,12]. The observed decrease of LDL-C concentration may be due to alterations in lipase and lipid transfer protein activities, as well as expression levels of LDL-C receptors. As a caveat, it should be noted that this study did not follow a group of untreated patients with periodontitis over the same time. Natural fluctuations in the levels of measured analytes might occur. It cannot therefore be ruled out that the reduction in LDL-C levels and increase in HDL-C levels, and the observed changes in other plasma variables, might reflect normal fluctuations, rather than any direct impact of periodontal treatment. The inclusion of such a control group would require the withholding of an important clinical intervention, which would have ethical implications.

Although studies have shown there to be an association between periodontitis and CVD, a definitive causal relationship has not yet been demonstrated. If a standard periodontal treatment could positively influence established risk markers for CVD, then this could be interpreted as sign of causality. Previous intervention studies suggest that periodontal treatment decreases the levels of inflammatory markers such as CRP, fibrinogen and IL-6 [12,14]. However, these studies were fairly small and the follow-up periods were only between 3 and 6 months. In the present study, the follow-up is longer and the treatment also included extractions and periodontal surgery; some of the previous intervention studies have only investigated the consequences of non-surgical debridement $[14,15]$.

The mean plasma concentrations of glucose increased by $0.25 \mathrm{mmol} / \mathrm{L}$, however the reason for this is unclear. Earlier studies have shown that periodontal treatment can have some effect on glucose concentration in patients with diabetes, especially those with type 2 diabetes [16]. The effect of periodontal treatment on glucose levels in patients without diabetes has not been reported. Although patients with diagnosed diabetes were excluded from participating in this study, $15 \%$ of the participants had glucose levels above $6.0 \mathrm{mmol} / \mathrm{L}$ at baseline. This is consistent with a study by Borrell et al. [17], which showed that the risk of undiagnosed diabetes increases with the presence of periodontitis.

Although the levels of CRP did not decrease significantly, the mean decrease after 12 months $(0.45 \mathrm{~g} / \mathrm{L})$ is comparable to data 
Table 2

Plasma concentrations of risk markers for atherosclerosis reported as median and interquartile range or median and standard deviation depending on distribution.

\begin{tabular}{|c|c|c|c|c|c|c|c|c|c|c|c|}
\hline & \multicolumn{3}{|l|}{ Baseline } & \multicolumn{4}{|c|}{ 3-month follow-up } & \multicolumn{4}{|c|}{ 12-month follow-up } \\
\hline & $\begin{array}{l}\text { All patients } \\
(n=68)\end{array}$ & $\begin{array}{l}\text { Non-smokers } \\
(n=39)\end{array}$ & $\begin{array}{l}\text { Smokers } \\
(n=29)\end{array}$ & $\begin{array}{l}3 \text { months } \\
(n=60)\end{array}$ & $\begin{array}{l}p \text {-Value, } \\
\text { baseline to } 3 \\
\text { months }\end{array}$ & $\begin{array}{l}\text { Non-smokers, } 3 \\
\text { months }(n=34)\end{array}$ & $\begin{array}{l}\text { Smokers, } \\
3 \text { months } \\
(n=26)\end{array}$ & $\begin{array}{l}12 \text { months } \\
(n=54)\end{array}$ & $\begin{array}{l}p \text {-Value, } \\
\text { baseline to } \\
12 \text { months }\end{array}$ & $\begin{array}{l}\text { Non-smokers, } \\
12 \text { months } \\
(n=32)\end{array}$ & $\begin{array}{l}\text { Smokers, } \\
12 \text { months } \\
(n=22)\end{array}$ \\
\hline Glucose (mmol/L) & $5.28(0.67)$ & $5.29(0.70)$ & $5.27(0.65)$ & $5.37(0.68)$ & - & $5.42(0.58)$ & $5.32(0.65)$ & $5.53(1.31)$ & 0.02 & $5.66(1.62)$ & $\begin{array}{l}5.36(0.61), \\
p^{*}=0.02\end{array}$ \\
\hline Triglycerides $(\mathrm{mmol} / \mathrm{L})^{\mathrm{a}}$ & $1.35(0.66)$ & $1.31(0.92)$ & $1.37(0.45)$ & $1.18(0.99)$ & - & $1.21(0.89)$ & $1.06(1.15)$ & $1.18(0.92)$ & - & $1.21(0.96)$ & $1.17(0.99)$ \\
\hline Total cholesterol $(\mathrm{mmol} / \mathrm{L})$ & $5.44(0.93)$ & $5.37(0.94)$ & $5.55(0.92)$ & $5.57(0.96)$ & - & $5.58(1.04)$ & $\begin{array}{l}5.57(0.86), \\
p^{*}=0.04\end{array}$ & $5.33(1.02)$ & - & $5.22(1.05)$ & $5.48(0.98)$ \\
\hline $\mathrm{HDL}-\mathrm{C}(\mathrm{mmol} / \mathrm{L})$ & $1.37(0.39)$ & $1.29(0.39)$ & $\begin{array}{l}1.49(0.41), \\
p^{*}=0.037\end{array}$ & $1.41(0.43)$ & - & $1.28(0.38)$ & $\begin{array}{l}1.58(0.45), \\
p^{*}=0.007\end{array}$ & $1.45(0.44)$ & 0.01 & $1.40(0.48)$ & $1.52(0.39)$ \\
\hline Lipid profile & $4.29(1.42)$ & $4.47(1.37)$ & $4.06(1.49)$ & $4.34(1.54)$ & - & $4.69(1.51)$ & $\begin{array}{l}3.87(1.48) \\
p^{*}=0.038\end{array}$ & $4.03(1.47)$ & 0.009 & $4.09(1.42)$ & $3.94(1.57)$ \\
\hline $\mathrm{LDL}-\mathrm{C}(\mathrm{mmol} / \mathrm{L})$ & $3.41(0.86)$ & $3.46(0.89)$ & $3.34(0.83)$ & $3.51(0.87)$ & - & $3.39(0.79)$ & $3.44(1.13)$ & $3.18(0.86)$ & 0.01 & $3.17(0.87)$ & $3.21(0.88)$ \\
\hline $\mathrm{CRP}(\mathrm{mg} / \mathrm{L})^{\mathrm{a}}$ & $1.35(2.10)$ & $2.08(2.72)$ & $\begin{array}{l}1.13(1.43) \\
p^{*}=0.014\end{array}$ & $1.08(1.20)$ & - & $1.56(1.55)$ & $\begin{array}{l}0.93(0.94) \\
p^{*}=0.039\end{array}$ & $1.16(1.27)$ & - & $1.16(1.16)$ & $1.20(1.77)$ \\
\hline Fibrinogen $(\mathrm{g} / \mathrm{L})$ & $2.54(0.36)$ & $2.54(0.36)$ & $2.54(0.37)$ & $2.53(0.46)$ & - & $2.54(0.40)$ & $2.52(0.53)$ & $2.60(0.38)$ & - & $2.53(0.42)$ & $\begin{array}{l}2.73(0.27) \\
p^{*}=0.021\end{array}$ \\
\hline Haptoglobin $(\mathrm{g} / \mathrm{L})$ & $1.33(0.39)$ & $1.29(0.40)$ & $1.39(0.38)$ & $1.32(0.39)$ & - & $1.28(0.36)$ & $1.38(0.43)$ & $1.21(0.37)$ & 0.004 & $1.14(0.33)$ & $1.31(0.41)$ \\
\hline
\end{tabular}

Bold shows difference between baseline, 3-month follow-up and 12-month follow-up. $p^{*}$-Values, italic and bold shows difference between non-smokers and smokers at the indicated time point.

a Variable not normally distributed, expressed as median and quartile range.

Table 3

Plasma concentrations of indicated cytokines reported as median and interquartile range or median and standard deviation depending on distribution.

\begin{tabular}{|c|c|c|c|c|c|c|c|c|c|c|c|}
\hline \multirow[t]{2}{*}{ Cytokine (ng/L) } & \multicolumn{3}{|l|}{ Baseline } & \multicolumn{4}{|c|}{ 3-month follow-up } & \multicolumn{4}{|c|}{ 12-month follow-up } \\
\hline & $\begin{array}{l}\text { All patients } \\
(n=67)\end{array}$ & $\begin{array}{l}\text { Non-smokers } \\
(n=38)\end{array}$ & $\begin{array}{l}\text { Smokers, } \\
p^{*}(n=29)\end{array}$ & $\begin{array}{l}\text { All patients, } \\
(n=59)\end{array}$ & $\begin{array}{l}p \text {-Value, } \\
\text { baseline to } 3 \\
\text { months }\end{array}$ & $\begin{array}{l}\text { Non-smokers } \\
(n=34)\end{array}$ & $\begin{array}{l}\text { Smokers, } \\
p^{*}(n=25)\end{array}$ & $\begin{array}{l}\text { All patients } \\
(n=44)\end{array}$ & $\begin{array}{l}p \text {-Value, } \\
\text { baseline to } 12 \\
\text { months }\end{array}$ & $\begin{array}{l}\text { Non-smokers } \\
(n=24)\end{array}$ & $\begin{array}{l}\text { Smokers, } \\
p^{*}(n=20)\end{array}$ \\
\hline IL-1 $\beta$ & $0.0(0.5)$ & $0.1(0.6)$ & $0.0(0.4)$ & $0.0(0.4)$ & & $0.2(0.6)$ & $0.0(0.3)$ & $0.15(0.4)$ & & $0.2(0.5)$ & $0.0(0.2),<0.04$ \\
\hline IL-4 & $1.4(11.1)$ & $2.6(21.0)$ & $0.8(12.9)$ & $1.6(7.1)$ & & $3.6(18.9)$ & $0.5(2.8)$ & $1.5(6.6)$ & & $1.8(22.1)$ & $0.9(4.0)$ \\
\hline IL-5 & $0.0(0.4)$ & $0.0(0.3)$ & $0.1(0.4)$ & $0.0(0.4)$ & & $0.0(0.7)$ & $0.0(0.2)$ & $0.0(0.4)$ & & $0.0(0.5)$ & $0.1(0.4)$ \\
\hline IL-6 & $8.6(20.5)$ & $10.0(16.0)$ & $8.2(19.7)$ & $7.8(14.0)$ & & $7.8(14.1)$ & $6.5(13.4)$ & $7.4(12.5)$ & & $7.3(18.4)$ & $7.4(12.0)$ \\
\hline IL-8 & $3.6(3.4)$ & $3.8(3.6)$ & $2.7(3.3)$ & $5.3(3.5)$ & & $4.1(5.1)$ & $2.6(2.1)$ & $3.7(2.8)$ & & $4.4(3.6)$ & $3.1(2.5)$ \\
\hline IL-10 & $2.2(4.1)$ & $2.2(4.0)$ & $2.2(3.9)$ & $1.2(3.3)$ & & $1.6(2.8)$ & $0.9(3.6)$ & $2.1(2.4)$ & & $2.2(2.1)$ & $1.5(2.4)$ \\
\hline IL-18 & $288(215)$ & $294(270)$ & $280(106)$ & 236 (149) & 0.002 & $240(170)$ & $230(116)$ & $197(81)$ & $<0.001$ & $183(83)$ & $222(74)$ \\
\hline IFN- $\gamma$ & $14.1(41.6)$ & $12.6(24.4)$ & $18.4(58.8)$ & $5.5(37.6)$ & & $3.4(19.0)$ & $\begin{array}{l}22.3(68.4) \\
<0.01\end{array}$ & $0.0(10.8)$ & $<0.001$ & $0.0(9.9)$ & $1.0(20.7)$ \\
\hline TNF- $\alpha^{\mathrm{a}}$ & $3.6(2.1)$ & $3.9(2.4)$ & $3.2(1.8)$ & $3.5(2.3)$ & & $4.0(2.5)$ & $2.9(1.8)$ & $3.6(2.0)$ & & $3.9(1.8)$ & $3.3(2.2)$ \\
\hline
\end{tabular}

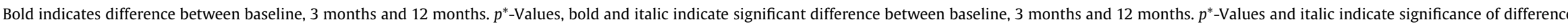
between non-smokers and smokers. $p$-Values $>0.05$ were not shown.

a Normal distribution. 
presented in a recent meta-analysis [18]. Whether CRP really is an independent risk factor for CVD remains debatable [19], however studies have shown that even small differences in CRP concentrations can reflect the risk of developing CVD [20]. In the present study, $12 \%$ of those examined at baseline did not come to the 3month examination and $21 \%$ did not come to the 1 -year follow-up. However, there were no significant differences in age, gender, smoking and levels of well-established risk factors such as CRP, glucose and cholesterol between those that dropped out and those who completed the study.

Treatment significantly and substantially decreased plasma concentrations of IL-18 and IFN- $\gamma$. The decrease of IL-18 could be of interest, since plasma concentrations of this cytokine are elevated in individuals with CVD [21]. This is especially so given that the decrease in IL-18 levels also correlates with better periodontal health. Plasma IL-18 has also been shown to predict death in patients with a pre-existing CVD [22] and also death in initially healthy individuals [23]. Animal models support the role of IL-18 in atherogenesis, and this role has been shown to partly involve an IFN- $\gamma$ dependent mechanism [24]. However, one must remember that no reductions were observed for the majority of the inflammatory markers that were investigated.

IFN- $\gamma$ plays a role in the development of atherosclerosis, both as a consequence of its effects on plaque progression/stability $[25,26]$ and via its negative impact on blood lipid trafficking (for review see Leon and Zuckerman [27]). In our present study, treatment reduced the plasma concentration of IFN- $\gamma$ by more than $90 \%$. The influence of treatment on IL-18 and IFN- $\gamma$ levels appeared to be specific, as it had no effect on the levels of IL-1 $\beta$, IL-4, IL-5, IL-6, IL-8, IL-10 and TNF- $\alpha$. This is somewhat surprising since the levels of some of these cytokines at baseline, most notably IL- 4 and IL-8, are different to those that are present in a matched control group of periodontally healthy subjects[28].

Although there were differences in the concentrations of antibodies against heat shock proteins between the patients in this study and a matched control group [28], treatment had no effect on these.

In the present study, all patients had severe chronic periodontitis with, on average, 48 periodontal pockets. In combination with a 'high bleeding on probing' index (45\%), this signifies there to have been a severe and widespread periodontal inflammation and thus it is likely that there was a potentially deleterious total body inflammatory load. The local clinical signs of this periodontal inflammatory burden were significantly reduced following periodontal treatment and the total body load of inflammation was thus considerably decreased. This, in turn, is likely to have an impact on other (systemic) diseases with an inflammatory origin.

In conclusion, standard treatment of severe periodontal disease induces systemic changes in several biochemical markers that reflect the risk for atherosclerosis. These findings are of significant relevance to our understanding of the association between these common diseases.

\section{Acknowledgements}

This study was supported with grants from the Swedish Dental Society and the Swedish research council \# K2006-73X-20138-013 . The generation of recombinant human Hsp60 was funded by the European Commission as part of the Concerted Action 'Heat Shock
Proteins in Inflammatory Diseases' (Project BMH4-CT98-3935).

\section{References}

[1] Borrell LN, Burt BA, Taylor GW. Prevalence and trends in periodontitis in the USA: the [corrected] NHANES, 1988 to 2000 [erratum appears in J Dent Res 2006; 85:287.]. J Dent Res 2005; 84:924-30.

[2] Bahekar AA, Singh S, Saha S, et al. The prevalence and incidence of coronary heart disease is significantly increased in periodontitis: a meta-analysis. Am Heart J 2007;154:830-7.

[3] Haraszthy VI, Zambon JJ, Trevisan M, et al. Identification of periodontal pathogens in atheromatous plaques. J Periodontol 2000;71:1554-60.

[4] Dorn BR, Dunn Jr WA, Progulske-Fox A. Invasion of human coronary artery cells by periodontal pathogens. Infect Immun 1999;67:5792-8.

[5] Pussinen PJ, Tuomisto K, Jousilahti P, et al. Endotoxemia, immune response to periodontal pathogens, and systemic inflammation associate with incident cardiovascular disease events. Arterioscler Thromb 2007;27:1433-9.

[6] Elkaim R, Dahan M, Kocgozlu L, et al. Prevalence of periodontal pathogens in subgingival lesions, atherosclerotic plaques and healthy blood vessels: a preliminary study. J Periodontal Res 2008;43:224-31.

[7] van Leuven SI, Franssen R, Kastelein JJ, et al. Systemic inflammation as a risk factor for atherothrombosis. Rheumatology (Oxford) 2008;47:3-7.

[8] Buhlin K, Gustafsson A, Pockley AG, et al. Risk factors for cardiovascular disease in patients with periodontitis. Eur Heart J 2003;24:2099-107.

[9] Ramfjord SP, Nissle RR. The modified Widman flap. J Periodontol 1974;45:601-7.

[10] Pockley AG, Wu R, Lemne C, et al. Circulating heat shock protein 60 is associated with early cardiovascular disease. Hypertension 2000;36:303-7.

[11] Pussinen PJ, Malle E, Metso J, et al. Acute-phase HDL in phospholipid transfer protein (PLTP)-mediated HDL conversion. Atherosclerosis 2001;155:297-305.

[12] Pussinen PJ, Jauhiainen M, Vilkuna-Rautiainen T, et al. Periodontitis decreases the antiatherogenic potency of high density lipoprotein. J Lipid Res 2004;45:139-47.

[13] Kinane DF, Lindhe J, Trombelli L. In: Lindhe J, Lang NP, Karring T, editors. Clinical periodontology and implant dentistry. Oxford: Blackwell Publishing Ltd.; 2008. p. 420-7.

[14] Montebugnoli L, Servidio D, Miaton RA, et al. Periodontal health improves systemic inflammatory and haemostatic status in subjects with coronary heart disease. J Clin Periodontol 2005;32:188-92.

[15] D’Aiuto F, Nibali L, Mohamed-Ali V, et al. Periodontal therapy: a novel non-druginduced experimental model to study human inflammation. J Periodontal Res 2004;39:294-9.

[16] Janket SJ, Wightman A, Baird AE, et al. Does periodontal treatment improve glycemic control in diabetic patients? A meta-analysis of intervention studies. J Dent Res 2005;84:1154-9.

[17] Borrell LN, Kunzel C, Lamster I, et al. Diabetes in the dental office: using NHANES III to estimate the probability of undiagnosed disease. J Periodontal Res 2007;42:559-65

[18] Paraskevas S, Huizinga JD, Loos BG. A systematic review and metaanalyses on C-reactive protein in relation to periodontitis. J Clin Periodontol 2008;35:277-90

[19] Paraskevas KI, Mikhailidis DP. C-reactive protein (CRP): more than just an innocent bystander? Curr Med Res Opin 2008;24:75-8.

[20] Ridker PM, Rifai N, Rose L, et al. Comparison of C-reactive protein and lowdensity lipoprotein cholesterol levels in the prediction of first cardiovascular events. N Engl J Med 2002;347:1557-65.

[21] Seta Y, Kanda T, Tanaka T, et al. Interleukin-18 in patients with congestive heart failure: induction of atrial natriuretic peptide gene expression. Res Commun Mol Pathol Pharmacol 2000;108:87-95.

[22] Blankenberg S, Tiret L, Bickel C, et al. AtheroGene investigators. Interleukin18 is a strong predictor of cardiovascular death in stable and unstable angina. Circulation 2002;106:24-30.

[23] Thompson SR, Novick D, Stock CJ, et al. Free Interleukin (IL)-18 levels, and the impact of IL18 and IL18BP genetic variation, in CHD patients and healthy men. Arterioscler Thromb Vasc Biol 2007;27:2743-9.

[24] Whitman SC, Ravisankar P, Daugherty A. Interleukin-18 enhances atherosclerosis in apolipoprotein $\mathrm{E}^{-1-}$ mice through release of interferon- $\gamma$. Circ Res 2002;90:E34-8.

[25] Gupta S, Pablo AM, Jiang X, et al. IFN- $\gamma$ potentiates atherosclerosis in ApoE knock-out mice. J Clin Invest 1997;99:2752-61.

[26] Buono C, Come CE, Stavrakis G, et al. Influence of interferon- $\gamma$ on the extent and phenotype of diet-induced atherosclerosis in the LDLR-deficient mouse. Arterioscler Thromb Vasc Biol 2003;23:454-60.

[27] Leon ML, Zuckerman SH. Gamma interferon: a central mediator in atherosclerosis. Inflamm Res 2005;54:395-411.

[28] Buhlin K, Hultin M, Norderyd O, et al. Risk factors for atherosclerosis in cases with severe periodontitis. J Clin Periodontol, in press, 2009. 